\begin{tabular}{|c|c|c|}
\hline BIODIK & $\begin{array}{c}\text { BIODIK: Jurnal IImiah Pendidikan Biologi } \\
\text { ISSN 2580-0922 (online), ISSN 2460-2612 (print) } \\
\text { Volume 07, Nomor 03, Tahun 2021, Hal. 01-10 } \\
\text { Available online at: } \\
\text { https://online-journal.unja.ac.id/biodik }\end{array}$ & BIODIK \\
\hline
\end{tabular}

Research Article

OPEN ACCESS

\title{
Inovasi Pembelajaran Berbasis Teknologi Informasi: Model Learning Cycle 5E Menggunakan Gather Town pada Materi Protista
}

\author{
(Information Technology-Based Learning Innovation: 5E Learning Cycle Model using Gather \\ Town on Protista Material)
}

\author{
Rifda Tanfiziyah*, Minnathul Khasanah, Riandi, Bambang Supriatno
}

Universitas Pendidikan Indonesia, Bandung

Jalan Dr. Setiabudi No. 229, Bandung 40415, Indonesia

*corresponding author : rifdatanfiziyah55@gmail.com

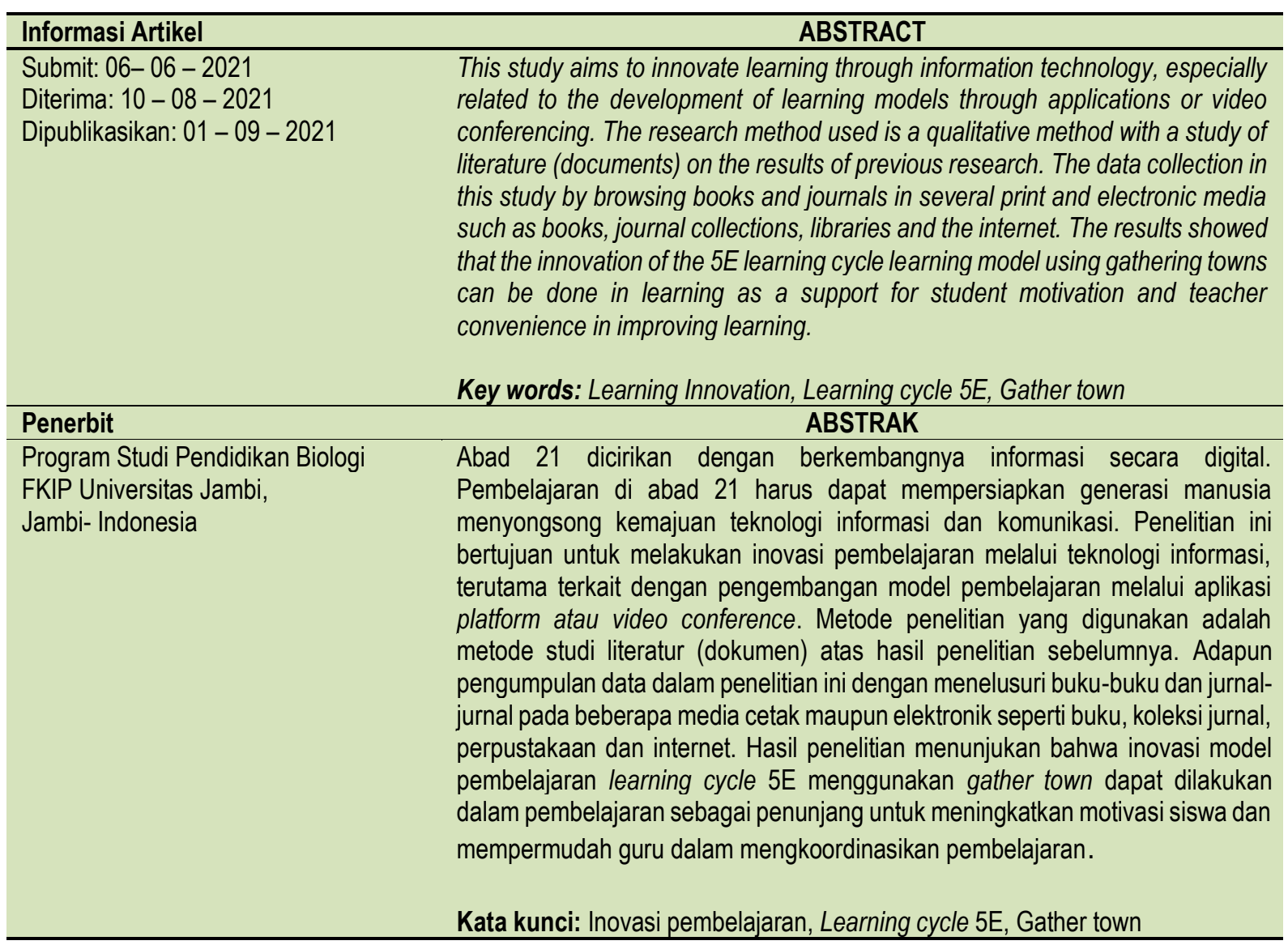

This BIODIK : Jurnal IImiah Pendidikan Biologi is licensed under a CC BY-NC-SA (Creative Commons Attribution-ShareAlike 4.0 International License) 


\section{PENDAHULUAN}

Pendidikan merupakan usaha yang terencana untuk mewujudkan suasana belajar dan proses pembelajaran agar siswa secara aktif dapat mengembangkan potensi dirinya (Nurkholis, 2013). Keberhasilan proses belajar mengajar dalam pendidikan di sekolah merupakan hal utama yang sangat penting. Pembelajaran sains, salah satunya pelajaran biologi sebagai bagian dari pendidikan yang memiliki peranan penting dalam peningkatan mutu pendidikan, khususnya dalam menghasilkan peserta didik yang mampu bertindak, berpikir kritis, kreatif, logis, dan berinisiatif dalam menanggapi isu di masyarakat yang diakibatkan oleh dampak perkembangan sains. Hal ini sejalan dengan penelitian Yulaikah et al., (2015) bahwa pembelajaran biologi adalah pembelajaran yang mendorong siswa secara aktif dalam memahami materi biologi dengan kemampuan daya nalar dan berfikir kritis, melibatkan proses penyelidikan secara ilmiah, serta penerapannya pada kehidupan nyata serta biologi mempunyai dimensi proses, produk, sikap ilmiah. Pesatnya perkembangan ilmu pengetahuan dan teknologi tersebut termasuk ilmu biologi membawa dampak terhadap pemilihan materi, metode, dan media pembelajaran serta model pembelajaran yang tepat agar dapat meningkatkan pengetahuan peserta didik serta dapat bersaing dalam menanggapi perkembangan sains tersebut (Rachmantika \& Wardono, 2019).

Model pembelajaran adalah kerangka konseptual yang melukiskan prosedur yang sistematis dengan mengorganisasikan pengalaman belajar untuk mencapai tujuan pembelajaran (Trianto, 2014); (Suprihatinigsih et al., 2016). Kurikulum di Negara Indonesia yang sedang berlaku saat ini adalah kurikulum 2013 revisi. Pada Kurikulum 2013 revisi menekankan bahwa proses pembelajaran harus berpusat pada siswa, bukan lagi berpusat pada guru. Akan tetapi pada keanyataanya, masih banyak guru atau pengajar yang menggunakan model pembelajaran konvensional dan masih jarang menerapkan suatu model pembelajaran yang inovatif. Berdasarkan hasil penelitian Boleng (2014) bahwa sebanyak kurang lebih 70\% guru SMA IPA masih menggunakan model pembelajaran konvensional karena materi lebih tersampaikan dan mudah dilaksanakan, meskipun demikian dari hasil penelitian tersebut ada sebanyak $30 \%$ guru yang berpendapat bahwa dengan pembelajaran konvensional siswa menjadi pasif dan miskonsepsi. Pendapat tersebut juga sejalan dengan Afif (2019) bahwa kecenderungan pendidikan pembelajaran di Indonesia secara umum dalam kurikulum dan model pembelajaran masih didominasi oleh pembelajaran konvensional dan kurang variatifnya model pembelajaran yang diterapkan oleh guru sehingga hanya terjadi komunikasi satu arah. Hal ini yang membuat daya serap siswa lemah karena hanya mendengarkan dari guru.

Perubahan paradigma pembelajaran dari yang awalnya berpusat pada guru ke yang berpusat pada siswa sangat diperlukan. Seorang guru harus bisa menerapkan strategi maupun model pembelajaran yang efektif dan inovatif yaitu sesuai dengan tujuan pembelajaran yang akan dicapai. Dalam proses pembelajaran harus terjadi interaksi dua arah antara guru dan siswa, artinya guru tidak harus selalu menjadi pihak yang lebih dominan. Menurut Maryati (2018) kegiatan belajar mengajar (KBM) dilandasi oleh prinsipprinsip berpusat pada peserta didik (student centered), mengembangkan kreativitas peserta didik, menciptakan kondisi menyenangkan dan menantang, mengembangkan beragam kemampuan yang bermuatan nilai, menyediakan pengalaman belajar.

Mengatasi permasalahan dia atas, maka guru harus menerapkan sebuah model pembelajaran inovatif yang berpusat pada siswa, karena model pembelajaran menempati peranan yang penting dalam 
kegiatan pembelajaran. Seperti yang diungkapkan oleh Nasution (2017) bahwa model pembelajaran memiliki kedudukan sebagai alat motivasi ekstrinsik dalam kegiatan pembelajaran. Motivasi ekstrinsik menurut Sardiman (2014); Fitrhiyah (2017) adalah motif-motif yang aktif dan berfungsinya karena adanya perangsang dari luar. Oleh karena itu, model pembelajaran berfungsi sebagai alat perangsang dari luar yang dapat membangkitkan motivasi belajar seseorang. Salah satu model pembelajaran yang berpusat pada siswa adalah learning cycle $5 \mathrm{E}$.

Tabel 1. Langkah-langkah model learning cycle 5E atau sintaks dari adaptaasi (Abell \& Volkmann, 2006); (Hanuscin \& Lee, 2008)

\begin{tabular}{|c|c|c|}
\hline Fase Learning Cycle 5E & Kegiatan Guru & Kegiatan Peserta Didik \\
\hline Engagement & $\begin{array}{l}\text { 1. Menentukan konteks atau pokok } \\
\text { bahasan yang akan dipelajari } \\
\text { 2. Memotivasi siswa. } \\
\text { 3. Mengidentifikasi ide sains terkini } \\
\text { dan miskonsepsi siswa. } \\
\text { 4. Mencari tahu apa yang perlu } \\
\text { dieksplorasi siswa di fase } \\
\text { berikutnya (fase eksplorasi). }\end{array}$ & $\begin{array}{l}\text { 1. Menghubungkan pengalaman } \\
\text { belajar yang telah siswa peroleh } \\
\text { sebelumnya dan pengalaman } \\
\text { belajar sekarang } \\
\text { 2. Memulai memikirkan konsep } \\
\text { yang akan dieksplorasi. } \\
\text { 3. Mendapatkan motivasi dan minat } \\
\text { siswa. }\end{array}$ \\
\hline Exploration & $\begin{array}{l}\text { 1. Memberikan serangkaian } \\
\text { pengalaman dasar atau } \\
\text { pengetahuan awal untuk siswa. } \\
\text { 2. Menentukan bagaimana siswa } \\
\text { memproses pemahaman } \\
\text { konseptual yang telah mereka } \\
\text { dapatkan. } \\
\text { 3. Mentukan apa yang perlu } \\
\text { dijelaskan oleh siswa pada tahap } \\
\text { berikutnya. }\end{array}$ & $\begin{array}{l}\text { 1. Menjelaskan dan menguji ide } \\
\text { siswa dengan pengalaman baru } \\
\text { (pengetahuan baru) } \\
\text { 2. Membandingkan ide siswa dengan } \\
\text { ide siswa lainnya dan penjelasan } \\
\text { dari guru. }\end{array}$ \\
\hline Explanation & $\begin{array}{l}\text { 1. Memberikan kesempatan bagi } \\
\text { siswa untuk menggunakan } \\
\text { pengetahuan sebelumnya untuk } \\
\text { mulai memahami konseptual dari } \\
\text { eksplorasi sebelumnya. } \\
\text { 2. Memperkenalkan bahasa formal, } \\
\text { istilah ilmiah, dan informasi } \\
\text { konten sesuai kebutuhan. } \\
\text { 3. Menentukan konsep apa yang } \\
\text { membutuhkan perhatian } \\
\text { instruksional lebih lanjut. } \\
\text { 4. Menentukan elaborasi yang akan } \\
\text { membantu scaffold learning di } \\
\text { fase berikutnya }\end{array}$ & $\begin{array}{l}\text { 1. Menunjukkan pemahaman siswa } \\
\text { saat ini. } \\
\text { 2. Mengembangkan penjelasan } \\
\text { berdasarkan pengalaman } \\
\text { sebelumnya. } \\
\text { 3. Gunakan bahasa formal, istilah } \\
\text { ilmiah, dan informasi konten } \\
\text { untuk membantu siswa dalam } \\
\text { mendeskripsikan dan } \\
\text { menjelaskan. }\end{array}$ \\
\hline Elaboration & $\begin{array}{l}\text { 1. Memberikan kesempatan untuk } \\
\text { menerapkan atau memperluas } \\
\text { ide-ide yang dapat dikembangkan } \\
\text { siswa melalui kegiatan baru. } \\
\text { 2. Menilai bagaimana siswa } \\
\text { menggunakan representasi } \\
\text { formal dari pengetahuan sains } \\
\text { (yaitu, istilah, rumus, dan } \\
\text { diagram). } \\
\text { 3. Menentukan sesuatu yang } \\
\text { penting untuk dievaluasi pada } \\
\text { tahap berikutnya. }\end{array}$ & $\begin{array}{l}\text { 1. Menerapkan dan mentransfer } \\
\text { pengetahuan dan keterampilan } \\
\text { siswa dalam konteks baru. } \\
\text { 2. Menghubungkan pengalaman } \\
\text { masa lalu (pengetahuan lama) } \\
\text { dengan aktivitas saat ini. } \\
\text { 3. Mengkomunikasikan ide } \\
\text { mereka saat ini. }\end{array}$ \\
\hline
\end{tabular}




\begin{tabular}{|c|c|c|}
\hline Fase Learning Cycle 5E & Kegiatan Guru & Kegiatan Peserta Didik \\
\hline Evaluation & $\begin{array}{l}\text { 1. Melakukan penilaian tentang } \\
\text { sejauh mana tingkat pemahaman } \\
\text { siswa untuk dapat menerapkan } \\
\text { konsep baru. } \\
\text { 2. Membangun metakognitif pada } \\
\text { siswa. } \\
\text { 3. Menentukan apa yang harus } \\
\text { terjadi dalam siklus pembelajaran } \\
\text { berikutnya. }\end{array}$ & $\begin{array}{l}\text { 1. Siswa meenilai pemahamanya } \\
\text { sendiri saat memecahkan suatu } \\
\text { masalah } \\
\text { 2. Memiliki sikap metakognitif } \\
\text { tentang pembelajaran yang } \\
\text { mereka pelajari }\end{array}$ \\
\hline
\end{tabular}

Model pembelajaran learning cycle 5E merupakan model pembelajaran yang berpusat pada siswa, dan didasarkan pada pandangan konstruktivisme sehingga dapat menciptakan pembelajaran di mana siswa aktif untuk mencari dan mengkonstruksi pengetahuannya sendiri (Yulianti, 2020). Beberapa penelitian menunjukkan bahwa penerapan model learning cycle 5E dapat meningkatkan prestasi akademik siswa (Tuna dan Kacar, 2013), keterampilan berpikir kritis (Adilah \& Budiharti, 2015), dan keakifan siswa (Setiawan et al., 2015). Pembelajaran dengan menggunakan model pembelajaran ini mampu memberikan kesempatan kepada siswa untuk mengoptimalkan cara belajar dan daya nalar siswa, memberikan kemudahan bagi siswa dalam memahami suatu konsep yang diajarkan dan siswa dapat lebih aktif dalam proses pembelajaran. Agar lebih memudahkan dalam proses pembelajaran menggunakan model learning cycle 5E maka untuk pengaplikasiannya menggunakan Platform.

Pembelajaran online dengan menggunakan video conference saat ini menjadi alternatif pilihan model pembelajaran. Begitu pula platform google meet dan zoom banyak digunakan dalam proses pembelajaran di sekolah. Akan tetapi setiap aplikasi tersebut memiliki kelebihan dan kekurangannya masing-masing. Selain kedua aplikasi tersebut, ada aplikasi baru yang fungsinya tak kalah sama yaitu aplikasi gather town. Gather town merupakan platform yang menggabungkan video call dengan peta 2D, memungkinkan pengguna berjalan-jalan dan berbicara dengan pengguna lain. Adapun dalam pembelajaran dengan menggunakan gather town guru harus dapat memastikan siswa mengikuti pembelajaran dalam waktu yang bersamaan, meskipun di tempat yang berbeda. Selain itu, guru selalu mengingatkan para murid untuk senantiasa masuk kelas online tepat waktu dan menyalakan video mereka serta ikut aktif selama pembelajaran. Sehingga kegiatan belajar mengajar yang sudah direncanakan akan tercapai dengan baik dan sesuai dengan tujuan pembelajaran. Oleh karena itu penulis tertarik untuk melakukan inovasi pembelajaran melalui teknologi informasi, terutama yang berkaitan dengan pengembangan model pembelajaran learning cycle 5E menggunakan Gather Town.

\section{METODE PENELITIAN}

Penelitian ini menggunakan metode studi literatur (dokumen) atas hasil penelitian sebelumnya. Menurut Cresswell (2013) menyatakan bahwa kajian literatur adalah ringkasan tertulis mengenai artikel dari jurnal, buku dan dokumen lain yang mendeskripsikan teori serta informasi baik masa lalu maupun saat ini mengorganisasikan pustaka ke dalam topik dan dokumen yang dibutuhkan. Pengumpulan data dalam penelitian ini dilakukan dengan menelusuri buku-buku dan jurnal-jurnal pada beberapa media cetak maupun elektronik seperti buku, koleksi jurnal, perpustakaan dan internet. Kemudian data yang relevan tersebut digunakan untuk mendukung gagasan penulis, dan dijadikan dasar dalam pembuatan artikel inovasi model pembelajaran menggunakan teknologi. Data sekunder dari berbagai hasil penelitian 
atau eksperimen adalah suatu jenis data yang kemudian disintesa menjadi satu kesatuan dalam memberikan informasi. Pencarian kata kunci difokuskan pada model pembelajaran learning cycle (5E) menggunakan teknologi untuk menunjang pembelajaran.

\section{HASIL PENELITIAN DAN PEMBAHASAN \\ Inovasi Pembelajaran Melalui Aplikasi Gather Town}

Sains sebagai ilmu yang dinamis, dimana penemuan-penemuan baru terus bermunculan setiap hari baik dalam ilmu sains maupun dalam pengajaran sains, kita bisa mendapatkan keuntungan dari perkembangan tersebut apabila terhubung ke dalam dunia TIK (Awolaju et al., 2010). Hal ini sesuai dengan pendapat Olugbenga \& Adebayo (2010) bahwa TIK telah menjadi fokus beberapa negara maju maupun berkembang yang dimana guru dan siswa memiliki sikap yang umumnya positif terhadap elearning dan kompetensi teknologi informasi yang semakin maju. Pada pembelajaran biologi menggunakan bantuan teknologi dapat membantu siswa memvisualisasikan objek yang sulit dilihat. Sebagai contoh, komputer dapat digunakan untuk menampilkan anatomi manusia dan hewan. Dengan bantuan teknologi mampu menghadirkan objek yang sulit diliat dengan mata telanjang menjadi dapat dilihat. Selain itu teknologi juga memudahkan komunikasi siswa dengan siswa, siswa dengan guru, baik di ruang kelas maupun di luar ruang kelas (Aina \& Kola, 2013).

Efektivitas pembelajaran dan pengajaran dalam sains bisa dilakukan melalui penerapan teknologi informasi dan komunikasi (TIK). Saat ini dunia berada di era teknologi dimana informasi tidak dibatasi oleh ruang dan waktu. Mengajar dan belajar bisa dilakukan dimana saja tidak lagi terbatas pada ruang kelas (Ajayi \& Ojo, 2010). Melalui pembelajaran online atau pembelajaran jarak jauh, sifat komunikasinya bisa tertutup antara satu siswa dengan guru maupun guru dengan siswa secara bersamaan (Monica \& Fitriawati, 2020). Metode pembelajaran jarak jauh dapat digunakan pada keempat komponen pendidikan yakni: pendidikan umum, memperkuat pengetahuan pendidik tentang mata pelajaran yang diajarkan, pengajaran pedagogi dan perkembangan anak, dan sebagai panduan menuju kelas yang lebih baik (Firman \& Rahayu, 2020).

Pembelajaran online pada masa sekarang bukan lagi hal yang baru. Kemajuan teknologi bisa menunjang sepenuhnya secara online sambal tetap terjadi komunikasi dengan teman sekelas, berpartisipasi dalam diskusi kelas dengan cara konfrensi video (video conference), berbagai dokumen, dan lainnya (Monica \& Fitriawati, 2020). Salah satu fitur yang sering digunakan dalam pembelajaran online adalah video vconfrence. Video conference adalah gabungan dari video dan audio dalam mode layer penuh, serta memungkinkan seorang dengan yang lain berbagi layar dan mendokumentasikan input sumber kamera (tatap muka). Video conference bekerja paling efektif ketika pembelajaran kelas dikontrol dalam jarak jauh, melalui microphone yang memungkinkan semua partisipan untuk memberikan komentar, split screen, dan multistream video feeds (Hyder, 2007). Video conference termasuk dalam synchronous learning yakni merupakan aktivitas yang dilakukan secara bersama-sama pendidik dan peserta didik. Synchronous learning bersifat real time artinya digunakan pada waktu tertentu. Synchronous learning yang menggunakan video conference dan teknik multimedia lainnya dapat memungkinkan pendidik dan anak didik berinteraksi satu sama lain pada saat yang bersamaan walaupun sedang berada ditempat yang berbeda (Chen et al., 2005); (Monica \& Fitriawati, 2020).

Banyak sekali aplikasi video conference yang dapat digunakan dalam pembelajaran yakni google meet, microsoft teams, skype, zoom dan lain-lain. Setiap dari aplikasi tersebut memiliki kelebihan dan 
kekurangannya masing-masing. Aplikasi zoom meeting menawarkan tools yang memudahkan penulis untuk melakukan e-learning, seperti share screen tool yang berfungsi untuk membagikan layar agar penulis dan siswa bisa melihat slide presentasi secara bersamaan, fitur chat yang bisa memudahkan interaksi dalam berbagi dokumen, fitur waiting room yang memungkinkan guru bisa memecah siswa ke dalam masing-masing room untuk berdiskusi misalnya, annotate dan fitur remote control yang akan mengizinkan peserta dalam mengontrol screen. Selain itu desain zoom dianggap sedikit rumit dibandingkan dengan skype karena beberapa fitur tertentu sulit ditemukan (Minhas et al., 2021). Aplikasi google meet, sering kali digunakan untuk pembelajaran online. Aplikasi tersebut memiliki kelebihan yakni, adanya fitur white board, tampilan video dengan resolusi yang tinggi, penggunaannya mudah, dapat mengundang 100 peserta untuk bergabung. Namun selain memiliki kelebihan terdapat beberapa kelemahan, yaitu tidak adanay fitur hemat data, belum semua fasilitas free, dan membutuhkan jaringan internet yang stabil (Mubarak et al., 2020).

Selain beberapa aplikasi yang sudah disebutkan untuk video conference baru-baru ini terdapat aplikasi gather town. Beberapa kelebihan dari aplikasi gather town dibandingkan dengan video confrene yang ada yakni (1) bisa lebih memudahkan guru dalem mengkoordinasikan kelas hanya menggunakan satu aplikasi, (2) menawarkan inovasi yang unik dari video confrence biasanya karena terdapat visual 2 dimensi (3) semua peserta memiliki kendali atas siapa yang ingin mereka ajak bicara, kapan pun mereka mau sehingga memduahkan interaksi siswa dalam berdiskusi, (4) dapat meningkatkan motivasi siswa dalam pembelajaran karena seolah-olah berada di kelas virtual yang sedang bermain video game, (5) guru dapat dengan mudah mengkoordinir apabila akan dilakukan pembagian kelompok untuk diskusi, (6) guru bisa mendesain ruang kelas virtual sesuai dengan kebutuhan dan keinginan. Selain memiliki kelebihan, terdapat beberapa kekurangan dari aplikasi gather town yakni (1) diperlukan pengenalan dan penggunaan mengenai aplikasi yang akan digunakan karena belum banyak yang mengetahui bagaiman penggunaannya, (2) aplikasi gather town berbayar untuk free hanya 25 orang saja, (3) tidak ada fitur mikrofon push-to-talk untuk menonaktifkan mikrofon yang berbunyi ketika bukan tepat pada waktunya.

Gather Town sendiri secara sederhana adalah platform yang menggabungkan video call dengan peta $2 \mathrm{D}$, memungkinkan pengguna berjalan-jalan dan berbicara dengan orang lain. Kelebihan Gather Town dibandingkan Zoom dan Google Meet adalah memposisikan sebagai platform yang tidak sekedar digunakan hanya untuk virtual meeting. Pengguna Gather Town akan diajak seolah-olah sedang bermain game saat melakukan virtual meeting. Jikalau ruangan virtual di Zoom dinamakan Room, di Gather Town disebut Space. Ruang virtual atau Space ini akan berbentuk map 2D dengan tampilan 8-bit. Tersedia berbagai map, mulai dari situasi rumah, ruangan meeting, ruang kelas, taman, aula, dan masih banyak lagi. Pengguna juga bisa bikin map sendiri dengan ide kreatifnya.

Pada gather town juga dapat menampilkan video call peserta dalam kotak-kotak kecil yang berada di atas layar. Pengguna bisa mematikan atau menghidupkan kamera dan mikrofon. Selain itu, ada tab chat di bawah pojok kiri layar untuk mengobrol dengan seluruh peserta atau bisa secara privat. Semua pengguna Gather Town juga bisa berbagi dokumen melalui Google Docs untuk berkolaborasi buat tugas atau pekerjaan. Selain itu, bisa menyisipkan link video YouTube dan Twitch yang bisa ditonton bersama.

Berikut ini cara menggunakan Gather Town untuk virtual meeting:

1. Untuk pengguna gratis buka situs https://gather.town/.

2. Kemudian, pilih "Launch Gather" untuk memulai virtual meeting.

3. Pilih "Create new space". Lalu akan muncul halaman untuk diisi nama Space yang dibuat beserta 
password-nya. Pilih juga map yang sudah tersedia.

4. Selanjutnya, akan diminta untuk membuat avatar dalam garis 8-bit. Isi nama dan pilih gaya rambut dan kostum yang digunakan.

5. Periksa juga kamera, mikrofon, dan speaker untuk memastikan bisa digunakan. Lalu, tekan "Join the Gathering".

6. Akhirnya kita sudah berada di ruang virtual layaknya video game jadul. Untuk mengundang teman bisa tekan opsi "Participant" dan pilih "Invite". Copy link dan bagikan ke teman atau kolega kamu.

7. Untuk menambahkan item, pilih ikon palu "Build" dan tekan "Open object picker".

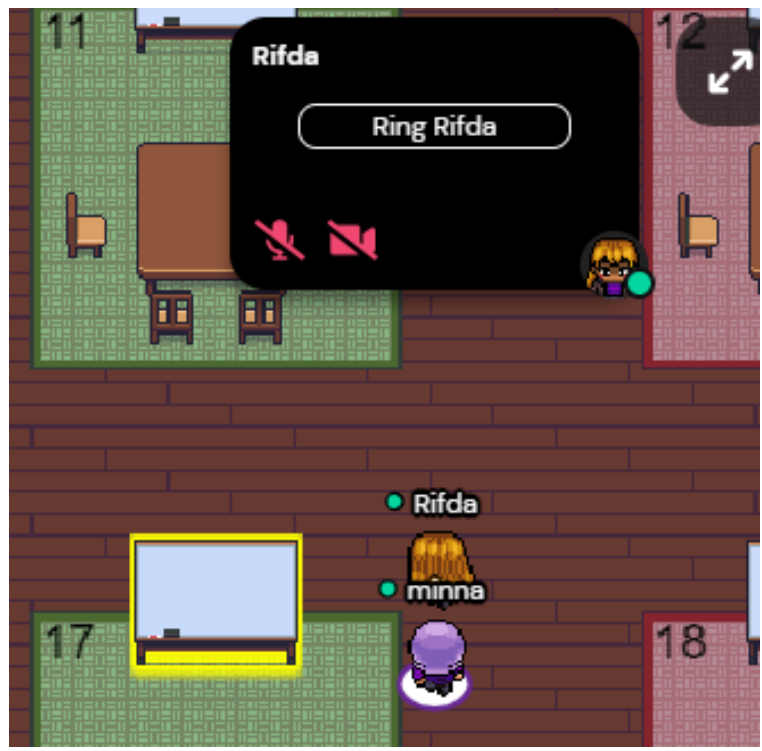

Gambar 1. Gambaran tampilan Gather Town

\section{Implementasi Model Pembelajaran Menggunakan Teknologi yang Dipilih}

Joyce \& Weil (1980) mendefinisikan model pembelajaran sebagai kerangka konseptual yang digunakan sebagai pedoman dalam melakukan pembelajaran. Dalam interaksi pembelajaran di kelas, baik pengajar maupun peserta didik mempunyai peranan yang sama penting. Perbedaannya terletak pada fungsi dan peranannya masing-masing. Untuk itu peranan pengajar dalam kegiatan pengajaran haruslah berupaya secara terus menerus membantu peserta didik membangun potensi-potensinya. Pengajar harus memilih dan menentukan strategi pembelajaran yang tepat untuk mencapai tujuan pengajaran. Model pembelajaran dapat dijadikan pola pilihan, artinya guru dapat memilih model yang sesuai dan efisien untuk mencapai tujuan pembelajarannya (Nurdyansyah dan Eni, 2016). Berikut ini dijelaskan bagaimana implementasi penggunaan fitur gather town menggunakan metode $5 \mathrm{E}$ dalam pembelajaran:

Tabel 2. Struktur model learning cycle 5E hasil inovasi atau sintaks menggunakan Gather Town.

\section{Fase Learning Cycle 5E}

Engagement Kegiatan Guru

1. Guru memberikan tutorial video mengenai cara menggunakan gather town yang diunggah sebelum materi berlangsung ( $\mathrm{H}-1$ pembelajaran)
Kegiatan Peserta Didik

1. Siswa menonton video tutorial mengenai cara penggunaan gather town dan memahaminya.

2. Siswa bersiap-siap memasuki 


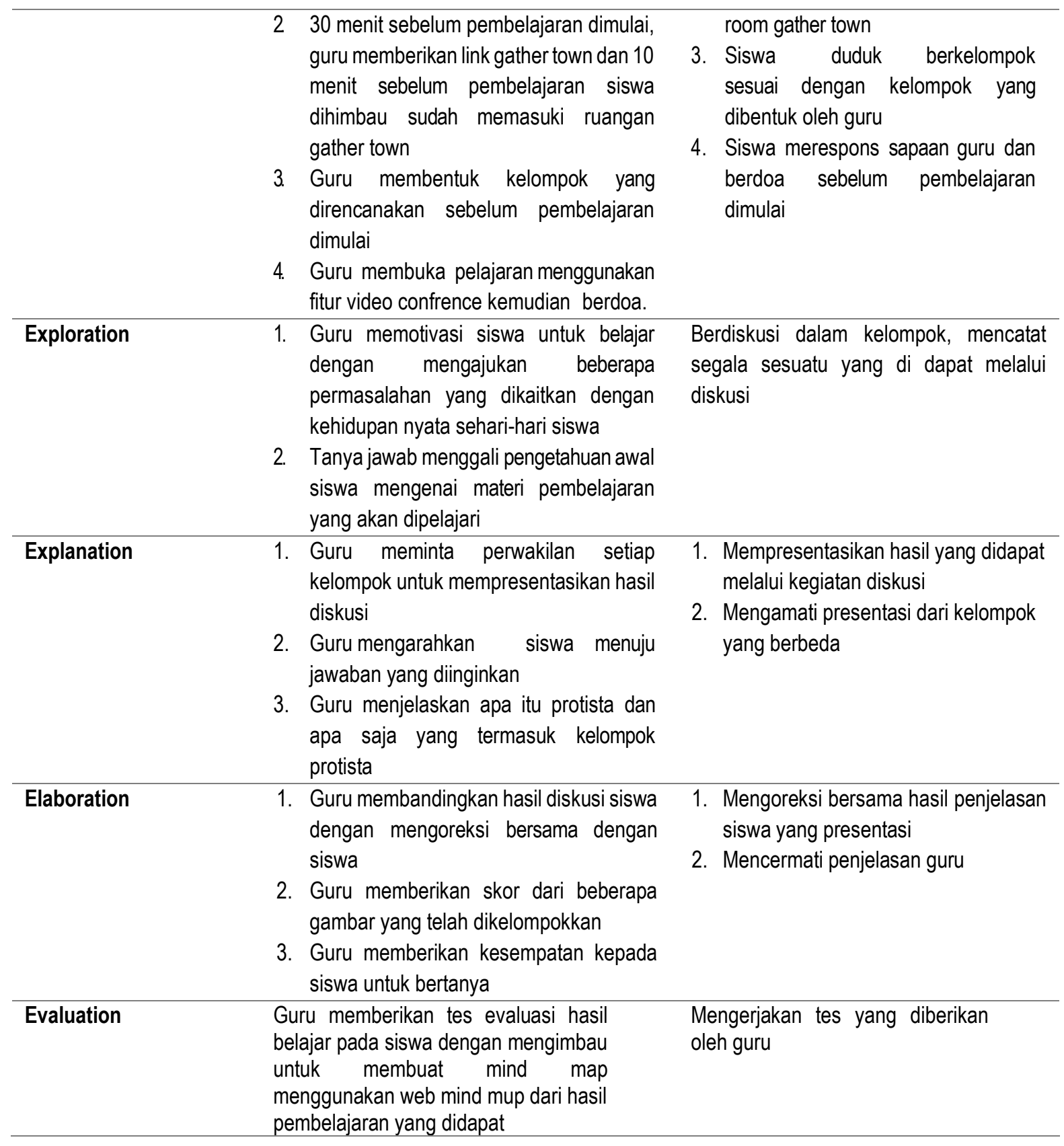

\section{SIMPULAN}

Inovasi model pembelajaran learning cycle 5E menggunakan gather town dapat dilakukan dalam pembelajaran sebagai penunjang untuk meningkatkan motivasi siswa dan mempermudah guru dalam mengkoordinasikan pembelajaran. Gather town menawarkan inovasi yang unik dari video confrence pada biasanya. Semua peserta memiliki kendali atas siapa yang ingin mereka ajak bicara, kapan pun mereka mau sehingga memudahkan interaksi siswa dalam berdiskusi. Selain itu tahap dari pembelajaran $5 \mathrm{e}$ menggunakan beberapa integrasi teknologi penunjang seperti mind mup dan whatsapp grup. Meskipun memiliki keunggulan, akan tetapi aplikasi ini juga masih memliki kelemahan bergantung dari sudut mana kebutuhan itu dapat dipenuhi. Hal ini dikarenakan aplikasi Gather town merupakan aplikasi video conference baru yang masih dalam tahap pengembangan dan pembaruan.

\section{$8 \quad$ Tanfiziyah, dkk}




\section{UCAPAN TERIMA KASIH}

Terima kasih penulis ucapkan terhadap pihak-pihak yang telah membantu menyelesaikan penelitian ini yaitu Minnathul Khasanah, S.Si selaku partner dalam menyelesaikan penulisan penelitian mengenai inovasi pembelajaran serta Dr. H. Riandi, M.Si.dan Dr. Bambang Supriatno, M.Si. selaku dosen pengampu mata kuliah Inovasi Pembelajaran Biologi Berbasis Teknologi yang telah senantiasa memberikan masukan dan saran, sehingga penulis mampu menyelesaikan penelitian ini dengan baik.

\section{RUJUKAN}

Adilah, D. N., \& Budiharti, R. (2015). Model Learning Cycle 7E Dalam Pembelajaran IPA Terpadu. Prosiding Seminar Nasional Fisika Dan Pendidikan Fisika (SNFPF) Ke-6, 6, 212-217.

Afif, N. (2019). Pengajaran dan Pembelajaran di Era Digital. IQ (IImu Al-Qur'an): Jurnal Pendidikan Islam, 2(01), 117-129. https://doi.org/10.37542/iq.v2i01.28

Aina, \& Kola, J. (2013). Effective Teaching and Learning in Science Education through Information and Communication Technology [ICT]. IOSR Journal of Research \& Method in Education (IOSRJRME), 2(5), 43-47. https://doi.org/10.9790/7388-0254347

Ajayi, I. A., \& Ojo, F. . (2010). Information and communication technology: a catalyst for democratized system of government. South- West Journal of Teacher Education, 3.

Awolaju, B. A., Akinloye, O. O., \& Ilorin, O. . (2010). Science education in democratized Nigeria: challenges and the way forward. South-West Journal of Teacher Education, 3, 615-622.

Boleng, D. T. (2014). Fenomena Penggunaan Pembelajaran Konvensional oleh Guru-Guru Biologi SMA Samarinda pada Kelas dengan Siswa Multietnis. Prosiding Seminar Nasional Biologi / IPA Dan Pembelajarannya, 141 - 148. https://doi.org/ISBN : 978-602-72185-0-5

Cresswell, J. W. (2013). Research Design Qualitative, Quantitative, and Mixed Methods Approaches third Edition, Terjemah Achmad Fawaid, Research Design Pendekatan Kualitatif, Kuantitatif, dan Mixed. Pustaka Pelajar.

Firman, F., \& Rahayu, S. (2020). Pembelajaran Online di Tengah Pandemi Covid-19. Indonesian Journal of Educational Science (IJES), 2(2), 81-89. https://doi.org/10.31605/ijes.v2i2.659

Fitrhiyah, E. A. (2017). Pengaruh Metode Ceramah dan Tanyajawab Terhadap Prestasi Hasil Belajar Siswa Kelas 5 SDN Paromahan Kecamatan Tambak Kabupaten Gresik. Jendela Pendidikan, 6(2), 167-180.

Hanuscin, D. L., \& Lee, M. H. (2008). Using the learning cycle as a model for teaching the learning cycle to preservice elementary teachers. Journal of Elementary Science Education, 20(2), 51-66. https://doi.org/10.1007/bf03173670

Hyder, K. (2007). The ELearning Guild's Handbook on Synchronous E-Learning. The E-Learning Guild. https://www.elearningguild.com/pdf/4/s\%0Aynchronousbook.pdf

Maryati, I. (2018). Penerapan Model Pembelajaran Berbasis Masalah Pada Materi Pola Bilangan Di Kelas Vii Sekolah Menengah Pertama. Mosharafa: Jurnal Pendidikan Matematika, 7(1), 63-74. https://doi.org/10.31980/mosharafa.v7i1.342

Minhas, S., Hussain, T., Ghani, A., \& Sajid, K. (2021). Exploring Students Online Learning: a Study of Zoom Application. Gazi University Journal of Science, 34(2), 171-178. https://doi.org/10.35378/gujs.691705

Monica, J., \& Fitriawati, D. (2020). Efektivitas Penggunaan Aplikasi Zoom Sebagai Media Pembelajaran Online Pada Mahasiswa Saat Pandemi Covid-19. Jurnal Communio: Jurnal Jurusan IImu Komunikasi, 9(2), 1630-1640. https://doi.org/10.35508/jikom.v9i2.2416 
Mubarak, M. R., Sulistyorini, S., \& Nurulita, A. (2020). Zoom Cloud Meeting: Media Alternatif dalam Pembelajaran Maharah Kalam di Tengah Wabah Virus Corona (Covid-19). Jurnal Bahasa Arab, $4(2), 221-223$.

Nasution, M. K. (2017). Penggunaan metode pembelajaran dalam peningkatan hasil belajar siswa. STUDIA DIDAKTIKA: Jurnal IImiah Bidang Pendidikan, 11(1), 9-16.

Nurkholis. (2013). PENDIDIKAN DALAM UPAYA MEMAJUKAN TEKNOLOGI Oleh: Nurkholis Doktor IImu Pendidikan, Alumnus Universitas Negeri Jakarta Dosen Luar Biasa Jurusan Tarbiyah STAIN Purwokerto. 1(1), 24-44.

Olugbenga, O. V., \& Adebayo, O. . (2010). Enforcing ICT knowledge on students as a means of enhancing academic performance in a democratized society: counselling and management perspective. SouthWest Journal of Teacher Education, 3, 376-400.

Rachmantika, A. R., \& Wardono. (2019). Peran kemampuan berpikir kritis siswa pada pembelajaran matematika dengan pemecahan masalah. Prosiding Seminar Nasional Matematika, 2, 439-443.

Setiawan, B., Alpusari, M., \& Syahrilfuddin. (2015). Penerapan Model Pembelajaran Learning Cycle (LC) untuk Meningkatkan Hasil Belajar IPA Siswa Kelas IVc SD Negeri 169 Pekanbaru. Jurnal Pendidikan, Lc, 1-13.

Suprihatinigsih, A., Rachman, M., \& Suhandini, P. (2016). Pengaruh Model Pembelajaran Sosiologi Berbasis Jelajah Alam Sekitar Terhadap Ketrampilan Memecahkan Masalah Siswa-Siswa SMA N 1 Mranggen. Journal of Educational Social Studies, 1(2), 11-23.

Yulaikah, S., A, D., \& A., R. (2015). Integrasi Scientific Inquiry dengan Kompetensi Profesional Guru Biologi pada Pembelajaran Biologi Abad Ke-21. Prosiding Seminar Nasional Pendidikan Biologi 21 Maret 2015., Malang(Universitas Muhamadiyah Malang).

Yulianti, Y. (2020). PENERAPAN MODEL LEARNING CYCLE 5E UNTUK MENINGKATKAN PEMBELAJARAN IPA. Jurnal Cakrawala Pendas, I(1), 1-9. https://doi.org/10.1145/3452144.3452248 